\title{
Application of microarrays to the analysis of the inactivation status of human X-linked genes expressed in lymphocytes
}

\author{
Ian W Craig*,1, Jonathan Mill ${ }^{1}$, Gavin M Craig ${ }^{1}$, Caroline Loat ${ }^{1}$ and Leonard C Schalkwyk ${ }^{1}$ \\ ${ }^{1}$ SGDP Centre, Institute of Psychiatry, Box PO 82, Denmark Hill, London SE5, UK
}

Dosage compensation in mammalian females is achieved by the random inactivation of one $\mathrm{X}$ chromosome early in development; however, inactivation is not complete. In addition to a majority of pseudoautosomal loci, there are genes that are expressed from both the active and the inactive $X$ chromosomes, and which are interspersed among other genes subject to regular dosage compensation. The patterns of X-linked gene expression in different tissues are of great significance for interpreting their impact on sex differences in development. We have examined the suitability and sensitivity of a microarray approach for determining the inactivation status of X-linked genes. Biotinylated cRNA from six female and six male lymphocyte samples were hybridised to Affymetrix HG-U133A microarrays. A total of $36 \mathrm{X}$-linked targets detected significantly higher levels of female transcripts, suggesting that these corresponded to sequences from loci that escaped, at least partly, from inactivation. These included genes for which previous experimental evidence, or circumstantial evidence, existed for their escape, and some novel candidates. Six of the targets were represented by more than one probe set, which gave independent support for the conclusions reached. European Journal of Human Genetics (2004) 12, 639-646. doi:10.1038/sj.ejhg.5201212

Published online 28 April 2004

Keywords: X-inactivation; sex-differences; gene expression

\section{Introduction}

Dosage compensation in mammalian females is achieved by the inactivation of one $\mathrm{X}$ chromosome early in development leading to the equality of $\mathrm{X}$-linked gene products between male and female cells. ${ }^{1}$ Not all X-linked genes are inactivated. Most loci in the pseudoautosomal regions on the tips of the long and short arms are active; there are, in addition, genes interspersed throughout the remainder of the chromosome that are expressed from both the active and, at varying levels, the inactive chromosomes. ${ }^{2-4}$ Some estimates indicate that $10-20 \%$ of X-linked genes escape inactivation, with the majority

*Correspondence: Professor I Craig, SGDP Centre, Box PO 82, Institute of Psychiatry, Denmark Hill, London SE5, UK. Tel: + 44207848 0018; Fax: + 44207848 0407; E-mail: i.craig@iop.kcl.ac.uk Received 26 June 2003; revised 25 February 2004; accepted 19 March 2004 located on Xp. Some of these have Y homologues, but many do not. ${ }^{5,6}$ Furthermore, there may be other genes on the $\mathrm{X}$ chromosome which are differentially imprinted, that is, selectively silenced, depending on their parent of origin. $^{7}$ Loci escaping inactivation appear to be found both in clusters and in isolation. ${ }^{8,9}$ The patterns of $\mathrm{X}$ linked gene expression in different tissues and, in particular, different regions of the brain are of great significance for interpreting their impact on behavioural sex differences. Due to the paucity of current data, determination of the inactivation status of additional genes remains critical for the formulation and resolution of rival theories concerning the nature and spread of the inactivation process.

An efficient means of determining the activity of an Xlinked gene is via the analysis of mouse-human somatic cell hybrids retaining only the inactive human $\mathrm{X}$ chromosome in a rodent background. ${ }^{5}$ As inactivation is effected at 
the level of transcription, detection of human-specific transcripts by RT-PCR is suggestive of an escape from inactivation. Inactivation can be confirmed by quantitation of the relevant transcripts from $\mathrm{XO}, \mathrm{XX}, \mathrm{XXX}$ or XXXX human cell lines. ${ }^{9,10}$ Other strategies are possible including observations on tissues, or cell lines, from females with skewed inactivation and we have previously presented an independent RT-PCR-based approach examining transcribed polymorphisms using cDNA from cloned human cell lines. ${ }^{11}$

Although much useful data have been generated by the above techniques, they are labour intensive and/or generally applicable only to a restricted number of loci. The majority of available data reflects inactivation status in established cell lines or somatic cell hybrids, and thus may not reflect the situation in vivo. Recourse to microarray 'chip technology' enables the screening of all X-linked genes for which sufficient sequence data are available. We have therefore investigated the potential of this system employing commercially available microarrays to assess quantitatively the comparative expression of X-linked genes in female lymphocytes to that in males. Sudbrak et $a l^{12}$ were the first to demonstrate the value of the microarray approach in such studies, employing X-linked EST clone inserts to interrogate transcripts from lymphoblastoid cell lines.

\section{Materials and methods}

Lymphocytes, RNA extraction and cDNA synthesis

Six male and six female volunteers provided $20 \mathrm{ml}$ blood samples and lymphocytes were isolated using Lymphoprep (Axis-Shield-PoC AS, Oslo). Total RNA was isolated subsequently with RNA-Bee (AMS Biotechnology). RNA was treated with DNase I (Qiagen, Crawley, UK) to avoid DNA contamination. The quality and purity of total RNA was assayed in a $2 \%$ agarose gel and the recovery was calculated after measuring absorbance with a spectrophotometer at $260 \mathrm{~nm}$.

Biotin labelled cRNA was prepared from $5 \mu \mathrm{g}$ of each total RNA, employing the manufacturer's reagents and protocols with the experiments being conducted in Affymetrix Laboratories, High Wycombe, England. cRNA products were subjected to quality control steps as follows: after spectrophotometric quantification they were hybridised to 'Test 3 arrays' providing information on $3^{\prime}$ compared to $5^{\prime}$ signal ratios for the human housekeeping genes. Each sample was hybridised to a single HG-U133A chip and processed using the standard protocol EukGE-WS2v4. The 12 chips were all scanned with the same scanner. Quality indicators from these hybridisations are summarised in Table 1 . On this basis, it was decided to eliminate female sample 3 and, to balance the numbers of male and female samples, male 7 was also excluded. In the remaining 10 samples, the range of scale factors was 0.85-2.1. The intensities were analysed with the Affymetrix Microarray Suite (MAS) version 5.0 'statistical algorithm', and the resulting signal values were scaled to give a trimmed mean of 100 for each chip. These values were then imported into the Affymetrix Data mining tool and also the $R$ statistical environment. The HG-U133A microarray displays sequences corresponding to approximately 18400 different transcripts and 14500 known genes, of which 772 are known X chromosome probe sets. Male and female samples were tested for difference using the Mann-Whitney test.

\section{Results}

Employing the Mann-Whitney test provided with the Affymetrix Data Mining Tool, a total of 36 probes with a female to male ratio above $1(P<0.05)$ were identified. Although this two-tailed nonparametric test is not corrected for multiple testing, it is otherwise extremely conservative. The overall female/male ratio for all sequences represented, based on five microarrays for each

Table 1 Quality control data for the 12 cRNA samples

\begin{tabular}{|c|c|c|c|c|c|c|c|}
\hline Sample & $c R N A$ yield $(\mu g)$ & Scale factor & Background & Noise & No. present (\%) & GAPDH & Actin \\
\hline 1 & 28.8 & 0.854 & 110.28 & 9.68 & 37.7 & 1 & 1.12 \\
\hline 2 & 43.44 & 1.288 & 68.59 & 3.63 & 40 & 0.91 & 1.2 \\
\hline 3 & 8.96 & 3.913 & 57.94 & 2.19 & 27.40 & 1.33 & 3.06 \\
\hline 4 & 29.08 & 1.1 & 60.54 & 2.82 & 43.60 & 0.94 & 1.13 \\
\hline 5 & 21.76 & 1.215 & 64.03 & 3.47 & 41.10 & 0.88 & 1.17 \\
\hline 6 & 13.2 & 1.561 & 65.06 & 3.78 & 40.20 & 1.14 & 1.2 \\
\hline 7 & 17.16 & 1.87 & 71.98 & 3.9 & 34 & 1.1 & 1.68 \\
\hline 8 & 52.4 & 1.036 & 38.37 & 3.43 & 46.30 & 1.1 & 1.1 \\
\hline 9 & 56.4 & 1.037 & 101.16 & 4.7 & 42.10 & 0.99 & 1.1 \\
\hline 10 & 48.72 & 1.7 & 87.37 & 4.61 & 40.10 & 0.94 & 1.1 \\
\hline 11 & 29.2 & 1.216 & 91.13 & 7.65 & 36.80 & 0.95 & 0.9 \\
\hline 12 & 16.56 & 2.1 & 60.41 & 2.95 & 33.30 & 1.1 & 1.7 \\
\hline
\end{tabular}

Quality control parameters are as follows: GAPDH and actin refer to the ratios of $3^{\prime} / 5^{\prime}$ representation of cRNA sequences obtained following amplification. 
sex, was 0.91. As an additional check on the validity of the identification process, means and standard deviations were calculated for the standardised signal outputs for the five female and five male samples for loci identified as giving significantly higher female:male ratios. These data together with information on chromosomal location (in $\mathrm{Mb}$ from Xpter) and probe derivation (Unigene accession details) are provided in Table 2. All probe sets represented on the microarray are listed and those with significant values are in bold.

Examination of those loci having evidence of escape from inactivation revealed four classes. The first is represented by genes with well-established records as escapees, the second by those for which previous weak or preliminary evidence for their escape is available, the third by loci for which previous evidence suggested normal inactivation and the fourth by candidates with no previous information available concerning their inactivation status.

\section{Loci with substantial pre-existing data supporting their escape from inactivation}

$\mathrm{X}$-linked genes that have active $\mathrm{Y}$ homologues

These are discussed sequentially in reported cytogenetic (Xpter-Xqter) order below.

Zinc-finger protein, X-linked, $Z F X$, (Xp22.2-p21.3) has a similar gene organisation and transcription profile to that of $Z F Y$ and escapes $\mathrm{X}$ inactivation. ${ }^{9,12-15}$

DEAD/H Box 3, X-linked, DDX3, (Xp11.3-p11.23) is one of a group of five X-linked loci with Y homologues in the nonpseudoautosomal region, which escape inactivation. ${ }^{16,17}$

Ubiquitously transcribed tetratricopeptide repeat gene on X chromosome, UTX, (Xp11.2) is homologous to the murine X-linked locus Utx. Both are reported to escape inactivation. ${ }^{18,19}$ Carrel et al $^{5}$ observed the expression of UTX from inactive $\mathrm{X}$ chromosomes in all six hybrid cell lines tested. (see: http://genetics.gene.cwru.edu/willard/ data/xin/genesurvey-all.xls for information on hybrid analysis).

\section{$\mathrm{X}$-linked genes that have inactive $\mathrm{Y}$ homologues}

Arylsulphatase C, ARSC2, comprises two microsomal isoenzyme forms, $\mathrm{s}$ and $\mathrm{f}$, with distinct transcripts. The coding sequences for both are localised at Xpter-p22.32, close to PAR1 and escape partially from inactivation. ${ }^{20}$ The extent to which the locus escapes inactivation may vary in different tissues with an overall ratio of female to male activity of 1.6, and ratios for peripheral blood white cells being particularly low. ${ }^{21}$ In the current examination, we obtained weak evidence for its escape from inactivation with one probe set indicating a female to male ratio of 1.33 with a $P$-value of 0.075 .
X-linked genes with existing evidence for escape from inactivation and that have no $\mathrm{Y}$ homologues

$\mathrm{X}$-linked loci escaping inactivation for which there are no apparent Y-linked homologues are represented in Table 2 by the eight loci detailed below. The eukaryotic translation initiation factor 2, gamma, EIF2S3, (Xp22.2-p22.1) unlike the mouse locus, apparently does not have a Y homologue; nevertheless, it appears to escape inactivation. ${ }^{22,23,5}$ Sedlin, SEDL, (Xp22.2-p22.1), which is mutated in spondyloepiphyseal dysplasia tarda, also escapes inactivation along with its closest flanking partners. ${ }^{24}$ Carrel et al ${ }^{5}$ reported its expression in all nine inactive-X-only hybrids tested. A similar result was reported for the gene encoding the cofactor required for SP1 transcriptional activation, subunit 2, CRSP2, (Xp11.4-p11.2), also referred to as TRAP170. ${ }^{25,26}$ Ubiquilin 2, UBQLN2, was localised to

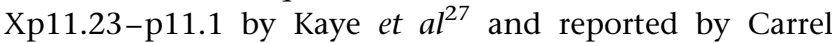
et $a l^{5}$ to escape from inactivation in two of nine hybrid cell lines. Another gene, structural maintenance of chromosomes 1-like, SMC1L1 is localised to a similar region (Xp11.22-p11.21) and reported to escape inactivation. ${ }^{5}$ On the long arm, the locus for armadillo repeat protein, ALEX2, (Xq21.33-q22.2) was found to escape inactivation in two of nine somatic cell hybrids tested. ${ }^{5}$ Also located on the long arm (Xq22) is the locus for collagen, type IV, alpha-6, COL4A6, which is mutated in some patients with Alport's syndrome. ${ }^{28,29}$ Higher female expression for COL4A6 was detected in two probe sets in the current analysis and it was found to escape inactivation in three of nine somatic hybrids examined by Carrel et $a^{5}$ The same approach suggests that the Homo sapiens hypothetical protein, FLJ21174, localised to Xq22.1, escapes inactivation in some (two of nine) hybrid backgrounds.

Loci with existing weak, conflicting or circumstantial evidence for escapee status

Montini et $a l^{30}$.identified a human cDNA, subsequently attributed to the locus, Sex comb on midleg, Drosophila, homologue-like 2, SCML2. Although Carrel et $a l^{5}$ failed to detect significant expression in the hybrid system, it is a possible escapee candidate by virtue of its chromosomal localisation at Xp22 in a region containing the MIC2 gene family and the sulphatase gene cluster. A similar argument applies to the gene encoding transducin-beta-like $1, \mathrm{X}$ linked, TBL1X, located in Xp22.3. ${ }^{31}$ The Chloride channel 4, CLCN4, locus is also located at Xp22.3. ${ }^{32}$ Interestingly, in Mus spretus the locus is X-linked, but autosomal (chromosome 7) in C57BL/J6, suggesting a recent evolutionary $\mathrm{X}$ rearrangement close to the pseudoautosomal boundary consistent with the gene's possible escapee status. The Rho guanine nucleotide exchange factor 6 , ARHGEF6, has been identified at the $\mathrm{X}$ breakpoint in a mother and son having an apparently balanced $\mathrm{X}: 21$ translocation (tXq26:21p11). Notably, wild-type mRNA for the locus was detected in the mother, consistent with 
Table 2 Comparison of male/female ratios of expression

\begin{tabular}{|c|c|c|c|c|c|c|c|c|c|}
\hline Probeset & Unigene & Gene symbol & Location & \multicolumn{2}{|c|}{ Female } & \multicolumn{2}{|c|}{ Male } & P-value & F/M ratio \\
\hline $\begin{array}{l}\text { 203769_s_at } \\
203768 \text { s_at } \\
203767 \text { s_at }\end{array}$ & Hs.79876 & $\begin{array}{l}\text { STS(ARAS) } \\
\text { STS(ARAS) } \\
\text { STS(ARAS) }\end{array}$ & $\begin{array}{l}6.60 \\
6.60 \\
6.60\end{array}$ & $\begin{array}{l}41 \\
38 \\
39\end{array}$ & $\begin{array}{r}4.06 \\
10.44 \\
6.84\end{array}$ & $\begin{array}{l}31 \\
34 \\
40\end{array}$ & $\begin{array}{r}11.68 \\
5.66 \\
7.80\end{array}$ & $\begin{array}{l}0.075 \\
0.619 \\
0.921\end{array}$ & $\begin{array}{l}1.33 \\
1.11 \\
0.97\end{array}$ \\
\hline $\begin{array}{l}\text { 201867_s_at } \\
213400 \text { s_at } \\
201868 \text { s_at } \\
201869 \text { s_at } \\
213401 \text { s_at }\end{array}$ & Hs.76536 & $\begin{array}{l}\text { TBL1 } \\
\text { TBL1 } \\
\text { TBL1 } \\
\text { TBL1 } \\
\text { TBL1 }\end{array}$ & $\begin{array}{l}9.03 \\
9.03 \\
9.03 \\
9.03 \\
9.03\end{array}$ & $\begin{array}{r}105 \\
185 \\
47 \\
51 \\
19\end{array}$ & $\begin{array}{r}12.31 \\
17.29 \\
5.86 \\
21.42 \\
4.83\end{array}$ & $\begin{array}{r}87 \\
194 \\
34 \\
57 \\
18\end{array}$ & $\begin{array}{r}6.95 \\
45.95 \\
25.58 \\
38.38 \\
14.57\end{array}$ & $\begin{array}{l}0.044 \\
0.484 \\
0.619 \\
0.766 \\
1.000\end{array}$ & $\begin{array}{l}1.21 \\
0.95 \\
1.38 \\
0.89 \\
1.04\end{array}$ \\
\hline 205148_s_at & Hs.199250 & CLCN4 & 9.54 & 22 & 18.48 & 6 & 1.79 & 0.024 & 3.74 \\
\hline 219351_at & HSSEDL6 & SEDL & 13.09 & 189 & 12.97 & 134 & 35.48 & 0.024 & 1.41 \\
\hline 206147_x_at & Hs. 171558 & SCML2 & 17.62 & 75 & 11.14 & 43 & 7.14 & 0.004 & 1.75 \\
\hline 205321_at & Hs.211539 & EIF2S3 & 23.43 & 298 & 80.92 & 182 & 53.00 & 0.024 & 1.63 \\
\hline $\begin{array}{l}214678 \text { _x_at } \\
207920 \text { _x_at } \\
217176 \text { s_at }\end{array}$ & Hs.2074 & $\begin{array}{l}\text { ZFX } \\
\text { ZFX } \\
\text { ZFX }\end{array}$ & $\begin{array}{l}23.55 \\
23.55 \\
23.55\end{array}$ & $\begin{array}{l}57 \\
49 \\
18\end{array}$ & $\begin{array}{r}15.39 \\
7.87 \\
5.68\end{array}$ & $\begin{array}{l}21 \\
32 \\
11\end{array}$ & $\begin{array}{r}10.72 \\
14.00 \\
4.48\end{array}$ & $\begin{array}{l}0.004 \\
0.044 \\
0.044\end{array}$ & $\begin{array}{l}2.74 \\
1.54 \\
1.74\end{array}$ \\
\hline $\begin{array}{l}\text { 203923_s_at } \\
217431 \text { _x_at } \\
203922 \text { s_at }\end{array}$ & Hs.88974 & $\begin{array}{l}\text { CGD } \\
\text { CGD } \\
\text { CGD }\end{array}$ & $\begin{array}{l}36.67 \\
36.67 \\
36.67\end{array}$ & $\begin{array}{r}589 \\
17 \\
315\end{array}$ & $\begin{array}{r}89.23 \\
7.03 \\
46.00\end{array}$ & $\begin{array}{r}475 \\
22 \\
309\end{array}$ & $\begin{array}{r}49.09 \\
4.09 \\
68.43\end{array}$ & $\begin{array}{l}\mathbf{0 . 0 4 4} \\
0.075 \\
0.619\end{array}$ & $\begin{array}{l}1.24 \\
0.78 \\
1.02\end{array}$ \\
\hline 218251_at & Hs.296433 & STRAIT11499 & 37.59 & 162 & 9.75 & 104 & 11.43 & 0.004 & 1.56 \\
\hline $\begin{array}{l}\text { 203990_s_at } \\
203992 \text { s_at } \\
203991 \text { s_at }\end{array}$ & Hs.13980 & $\begin{array}{l}\text { UTX } \\
\text { UTX } \\
\text { UTX }\end{array}$ & $\begin{array}{l}43.78 \\
43.78 \\
43.78\end{array}$ & $\begin{array}{r}65 \\
116 \\
51\end{array}$ & $\begin{array}{r}6.78 \\
11.35 \\
9.41\end{array}$ & $\begin{array}{l}44 \\
65 \\
29\end{array}$ & $\begin{array}{r}5.86 \\
14.77 \\
14.19\end{array}$ & $\begin{array}{l}0.004 \\
0.004 \\
0.024\end{array}$ & $\begin{array}{l}1.48 \\
1.78 \\
1.74\end{array}$ \\
\hline $\begin{array}{l}\text { 213200_at } \\
217349 \text { s_at }\end{array}$ & Hs.75667 & $\begin{array}{l}\text { SYP } \\
\text { SYP }\end{array}$ & $\begin{array}{l}48.07 \\
48.07\end{array}$ & $\begin{array}{l}32 \\
18\end{array}$ & $\begin{array}{l}14.13 \\
12.05\end{array}$ & $\begin{array}{l}10 \\
16\end{array}$ & $\begin{array}{l}3.17 \\
5.37\end{array}$ & $\begin{array}{l}\mathbf{0 . 0 1 2} \\
0.921\end{array}$ & $\begin{array}{l}3.13 \\
1.14\end{array}$ \\
\hline 207739_s_at & Hs.278444 & GAGE5 & 48.24 & 20 & 5.13 & 14 & 4.23 & 0.044 & 1.43 \\
\hline 201589_at & Hs. 211602 & SMC1L1 & 53.37 & 291 & 27.50 & 194 & 37.19 & 0.004 & 1.50 \\
\hline 215884_s_at & Hs.4552 & UBQLN2 & 55.56 & 324 & 38.48 & 269 & 44.09 & 0.044 & 1.21 \\
\hline $\begin{array}{l}\text { 212727_at } \\
212729 \text { at } \\
212728 \text { at }\end{array}$ & Hs.11101 & $\begin{array}{l}\text { KIAA1232 } \\
\text { KIAA1232 } \\
\text { KIAA1232 }\end{array}$ & $\begin{array}{l}68.43 \\
68.43 \\
68.43\end{array}$ & $\begin{array}{l}65 \\
63 \\
10\end{array}$ & $\begin{array}{r}17.00 \\
16.53 \\
1.82\end{array}$ & $\begin{array}{l}42 \\
56 \\
10\end{array}$ & $\begin{array}{r}16.40 \\
10.58 \\
1.77\end{array}$ & $\begin{array}{l}\mathbf{0 . 0 4 4} \\
0.365 \\
0.615\end{array}$ & $\begin{array}{l}1.53 \\
1.14 \\
0.97\end{array}$ \\
\hline 219650_at & Hs.89306 & FLJ20105 & 70.29 & 8 & 3.41 & 4 & 1.77 & 0.024 & 2.26 \\
\hline
\end{tabular}


Table 2 continued

\begin{tabular}{|c|c|c|c|c|c|c|c|c|c|}
\hline \multirow[b]{2}{*}{ Probeset } & \multirow[b]{2}{*}{ Unigene } & \multirow[b]{2}{*}{ Gene symbol } & \multirow[b]{2}{*}{ Location } & \multicolumn{2}{|c|}{ Female } & \multicolumn{2}{|c|}{ Male } & \multirow[b]{2}{*}{ P-value } & \multirow[b]{2}{*}{ F/M ratio } \\
\hline & & & & Mean & $S D$ & Mean & $S D$ & & \\
\hline $\begin{array}{l}\text { 208859_s_at } \\
208860 \text { s_at } \\
208861 \text { s_at } \\
211022 \text { s_at }\end{array}$ & Hs.96264 & $\begin{array}{l}\text { ATRX } \\
\text { ATRX } \\
\text { ATRX } \\
\text { ATRX }\end{array}$ & $\begin{array}{l}75.52 \\
75.52 \\
75.52 \\
75.52\end{array}$ & $\begin{array}{r}135 \\
131 \\
239 \\
43\end{array}$ & $\begin{array}{l}49.24 \\
35.33 \\
17.15 \\
13.74\end{array}$ & $\begin{array}{r}85 \\
101 \\
201 \\
37\end{array}$ & $\begin{array}{l}16.63 \\
22.84 \\
64.62 \\
13.91\end{array}$ & $\begin{array}{l}0.044 \\
0.187 \\
0.187 \\
0.266\end{array}$ & $\begin{array}{l}1.59 \\
1.30 \\
1.19 \\
1.18\end{array}$ \\
\hline 214615_at & Hs. 296433 & P2Y10 & 76.96 & 44 & 5.87 & 34 & 6.42 & 0.044 & 1.29 \\
\hline $\begin{array}{l}216809 \text { at } \\
216779 \text { at } \\
216778 \text { s_at }\end{array}$ & Hs.307358 & $\begin{array}{l}\text { CYLC1 } \\
\text { CYLC1 } \\
\text { CYLC1 }\end{array}$ & $\begin{array}{l}81.89 \\
81.89 \\
81.89\end{array}$ & $\begin{array}{l}52 \\
34 \\
11\end{array}$ & $\begin{array}{r}10.37 \\
9.02 \\
2.48\end{array}$ & $\begin{array}{l}38 \\
46 \\
13\end{array}$ & $\begin{array}{r}7.28 \\
11.31 \\
12.54\end{array}$ & $\begin{array}{l}\mathbf{0 . 0 2 4} \\
\mathbf{0 . 0 4 4} \\
0.841\end{array}$ & $\begin{array}{l}1.38 \\
0.73 \\
0.91\end{array}$ \\
\hline 201132_at & Hs.278857 & HNRPH2 & 99.43 & 236 & 32.35 & 168 & 23.13 & 0.004 & 1.40 \\
\hline 203404_at & Hs.48924 & ALEX 2 & 99.58 & 43 & 9.05 & 28 & 14.29 & 0.075 & 1.55 \\
\hline 211276_at & Hs. 17481 & my048 & 100.05 & 13 & 2.81 & 6 & 2.16 & 0.004 & 1.99 \\
\hline 219335_at & Hs.119699 & FLJ12969 & 100.53 & 58 & 10.36 & 39 & 5.41 & 0.004 & 1.49 \\
\hline 202371_at & Hs.194329 & FLJ21174 & 101.50 & 66 & 9.70 & 46 & 13.14 & 0.024 & 1.45 \\
\hline $\begin{array}{l}\text { 210945_at } \\
\text { 213115_at } \\
\text { 213992_at } \\
\text { 217343_at }\end{array}$ & Hs.408 & $\begin{array}{l}\text { COL4A6 } \\
\text { COL4A6 } \\
\text { COL4A6 } \\
\text { COL4A6 }\end{array}$ & $\begin{array}{l}\mathbf{1 0 6 . 1 7} \\
\mathbf{1 0 6 . 1 7} \\
106.17 \\
106.17\end{array}$ & $\begin{array}{l}20 \\
87 \\
46 \\
13\end{array}$ & $\begin{array}{r}2.21 \\
9.90 \\
10.04 \\
4.55\end{array}$ & $\begin{array}{r}12 \\
109 \\
37 \\
13\end{array}$ & $\begin{array}{r}5.32 \\
16.98 \\
17.53 \\
4.68\end{array}$ & $\begin{array}{l}\mathbf{0 . 0 2 4} \\
\mathbf{0 . 0 2 4} \\
0.619 \\
0.921\end{array}$ & $\begin{array}{l}1.67 \\
0.80 \\
1.22 \\
1.02\end{array}$ \\
\hline $\begin{array}{l}\text { 212414_s_at } \\
214298 \text { _a at } \\
212413 \text { at } \\
213666 \text { at } \\
212415 \text { at }\end{array}$ & Hs.90998 & $\begin{array}{l}\text { SEPT6 } \\
\text { SEPT6 } \\
\text { SEPT6 } \\
\text { SEPT6 } \\
\text { SEPT6 }\end{array}$ & $\begin{array}{l}117.40 \\
117.40 \\
117.40 \\
117.40 \\
117.40\end{array}$ & $\begin{array}{l}480 \\
223 \\
143 \\
131 \\
216\end{array}$ & $\begin{array}{l}61.15 \\
42.46 \\
21.84 \\
42.97 \\
54.71\end{array}$ & $\begin{array}{r}321 \\
154 \\
113 \\
98 \\
164\end{array}$ & $\begin{array}{l}83.46 \\
27.87 \\
12.75 \\
22.70 \\
53.08\end{array}$ & $\begin{array}{l}0.004 \\
0.024 \\
0.044 \\
0.123 \\
0.187\end{array}$ & $\begin{array}{l}1.50 \\
1.45 \\
1.26 \\
1.34 \\
1.32\end{array}$ \\
\hline 218499_at & Hs.23643 & MST4 & 129.76 & 279 & 52.41 & 210 & 52.35 & 0.044 & 1.33 \\
\hline $\begin{array}{l}\text { 218668_s_at } \\
218669 \text { at }\end{array}$ & Hs.225979 & $\begin{array}{l}\text { LOC57826 } \\
\text { LOC57826 }\end{array}$ & $\begin{array}{l}129.95 \\
129.95\end{array}$ & $\begin{array}{l}130 \\
149\end{array}$ & $\begin{array}{r}15.25 \\
9.54\end{array}$ & $\begin{array}{r}90 \\
152\end{array}$ & $\begin{array}{l}25.00 \\
41.97\end{array}$ & $\begin{array}{l}\mathbf{0 . 0 2 4} \\
0.619\end{array}$ & $\begin{array}{l}1.45 \\
0.98\end{array}$ \\
\hline 219626_at & Hs.24078 & FLJ12649 & 134.00 & 89 & 19.54 & 49 & 19.39 & 0.012 & 1.79 \\
\hline 209539_at & Hs.79307 & ARHGEF6 & 134.46 & 321 & 23.43 & 289 & 10.34 & 0.004 & 1.11 \\
\hline 214633_at & Hs.157429 & sox 3 & 138.29 & 23 & 7.95 & 7 & 4.12 & 0.012 & 3.38 \\
\hline $\begin{array}{l}\text { 216592_at } \\
206609 \text { at }\end{array}$ & Hs. 247705 & $\begin{array}{l}\text { MAGEC1 } \\
\text { MAGEC1 }\end{array}$ & $\begin{array}{l}139.69 \\
139.69\end{array}$ & $\begin{array}{l}13 \\
26\end{array}$ & $\begin{array}{l}4.04 \\
7.72\end{array}$ & $\begin{array}{r}5 \\
22\end{array}$ & $\begin{array}{l}1.73 \\
9.59\end{array}$ & $\begin{array}{l}\mathbf{0 . 0 1 2} \\
0.766\end{array}$ & $\begin{array}{l}2.73 \\
1.18\end{array}$ \\
\hline 206216_at & Hs. 104865 & STK23 & 151.51 & 64 & 10.67 & 34 & 17.49 & 0.024 & 1.86 \\
\hline
\end{tabular}

Expression level data for recognised X-linked genes are detected in the screen for $\mathrm{X}$ loci escaping inactivation. Where multiple probe sets correspond to a given locus, values indicating those with significantly higher female expression are in bold. Male and female values represent the mean of five observations. $\mathrm{SD}=$ standard deviation and $\mathrm{F} / \mathrm{M}$ ratio = mean female expression/mean male expression. The values presented are expressed relative to an arbitrary target intensity (TGT) of 100 , averaging data across the whole microarray. The $P$-values represent the probability of observing the observed deviation from equality of male-female expression by chance. Locations are given in Mb from Xpter. (Note the pter-qter order may differ from those derived from reported cytogenetic positions).

her normal phenotype, ${ }^{33,34}$ which is contrary to the normal expectation that genes on the intact $\mathrm{X}$ in translocation carrier females are inactive. Somatic cell hybrid studies, nevertheless, suggest that ARHGEF6 is normally inactivated. In our analysis, the observed female/male ratio (1.11) suggested only very partial escape, but with a highly significant $P$-value (0.004). SRY-related HMG-box gene 3, SOX3, (Xq26-q27) is homologous to the $S R Y$ locus on the $\mathrm{Y}$ chromosome and its conservation in marsupials suggests that SOX3 represents the ancestral gene from which $S R Y$ was derived; it may therefore have an unusual inactivation profile. ${ }^{35,36}$ 
Loci for which previous evidence suggested normal inactivation

Earlier reports concerning the following loci detected in our current screen failed to provide evidence of significant escape from inactivation: chronic granulomatous disease, $C G D,(\mathrm{Xp} 21.1),{ }^{37,38}$.alpha thalassemia/mental retardation syndrome, X-linked, ATRX, (Xq13), which results from

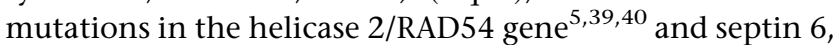
SEPT6. ${ }^{5}$ Ste20-like kinase, MST4, (Xq26) also appeared to be regularly inactivated in studies on X-only-somatic cell hybrids. ${ }^{41}$

\section{Established loci lacking evidence either for, or against,} inactivation

These include U2 small nuclear ribonucleoprotein auxiliary factor, small subunit 2, U2AF1RS2, (Xp22.1) a human homologue of the imprinted mouse gene U2af1rs1, ${ }^{42}$ synaptophysin, SYP, (Xp11.23-p11.22) heterogeneous ribonuclear protein $\mathrm{H} 2$, HNRPH2, (Xq22), cylicin 1, CYCL1, (Xq21.1), the melanoma antigen - family C, MAGEC1, (Xp26) and the serine/threonine kinase 23, STK23, (Xq28).

Finally, there are several poorly characterised X-linked loci, which have been identified in this screen as potential escapees. These are: the loci encoding the Homo sapiens hypothetical proteins, PRO0386, (Xp22.31); STRAIT 11499, (Xp11.4); G antigen 5, GAGE5/7, (Xp11.4-p11.2); FLJ20105, (Xq12); the putative purinergic receptor, P2Y10, (Xq21.1); FLJ2969, (Xq22.1-q22.3); the brain my048 protein, locus also at Xq22.1-q22.3; the Homo sapiens hypothetical proteins, LOC5726, at (Xq25) and FLJ12649, (Xq26.3) and the Homo sapiens protein, $K I A A 1232$, for which no subregional localisation has been reported.

(Unigene accession numbers for these and other loci without literature references are provided in Table 2).

\section{Discussion}

Two of the most common previously employed strategies to assess inactivation status are to analyse methylation profiles at, or adjacent to, the locus of interest and to examine the expression of transcripts from the inactive $\mathrm{X}$ chromosome isolated in somatic cell hybrids employing RT-PCR. The former is based on the assumption that methylation is associated with inactive status, but does not assay expression directly and cannot provide information on the extent to which loci might escape the inactivation process. The latter is highly adaptable; however, it can only relate to the inactivation status in a cultured somatic cell hybrid background. ${ }^{2,5,6}$ Various attempts to overcome both of these limitations have been made. The recent availability of reliable microarray technology provides a powerful approach to examine transcription profiles and advances in both the preparation of arrays and in the software available for the analysis of signal intensity, have brought the realistic possibility of detecting fractional rather than fold differences in expression. This in turn provides an opportunity to examine subtle sex differences in gene expression and, in this investigation, we have analysed the relative expression of X-linked loci to evaluate the potential of the approach to investigate inactivation status.

The selection of lymphocytes as the tissue of choice was dictated by ease of access and in lymphoblastoid cell lines derived from them, about $50 \%$ of the 5184 genes represented on the microarrays used in one study were expressed at sufficient levels for analysis. ${ }^{43}$ Although such expression studies indicated some natural variation in human gene expression, with some familial aggregation suggesting the existence of high and low expressing alleles - our investigations reported only results for which there were consistent patterns of expression differentials between the five male and female replicates. Although possible cross-hybridisation to Y-related sequences may be difficult formally to eliminate in some cases (and would in any case tend to reduce female/male ratios), the detection of loci for which there was previous evidence of their escapee status and for which no Y homologues have been reported supports the general potential of this approach. Indeed, given the reproducibility of signals observed and that in several examples the same loci have been identified by more than one probe set, we have not attempted replication by other techniques, which are not directly comparable and unlikely to detect subtle differences in expression levels; but rather have provided an overall evaluation of the method's potential by comparisons with the extensive data already available in the literature.

Sudbrak et al, ${ }^{12}$ employed cDNAs bound to microarrays to interrogate transcripts from lymphoblastoid lines. Their overall pattern of observation was similar to those reported here, with about $4 \%$ escapees - equally distributed between short and long arms, and with many of the same loci being identified. Clearly, the microarray approach will enable an efficient strategy to obtain a better understanding of the tissue and individual differences in inactivation profiles as more studies are completed.

The results obtained in this investigation have been extremely encouraging in that, of the 20 well-studied loci which we identified as having significantly higher female expression levels, 11 had previous supporting evidence for their escape from inactivation and five had provisional, or circumstantial, evidence. Only four characterised loci had previous contrary evidence to the conclusions reached in our study. The remaining loci, the majority of which encoded hypothetical proteins, had no associated information concerning their inactivation status.

We also examined the data for some genes that were not detected in the screen for $\mathrm{X}$ loci escaping inactivation, but for which previous data supported their inactivation status as either escapees, or as normally inactivated. 
Table 3 Expression level data for recognised X-linked genes believed to escape inactivation, but which were not detected by microarray analysis

\begin{tabular}{|c|c|c|c|c|c|c|c|c|c|c|}
\hline & Probe ID & GENE & Sample 1 & Sample 2 & Sample 3 & Sample 4 & Sample 5 & Mean & $S D$ & Female/male ratio \\
\hline Female & 208823_s_at & PCTK1 & 134 & 128 & 47 & 112 & 68 & 97.8 & 38.3 & \\
\hline Male & $208823 \mathrm{~s}$ at & & 90 & 80 & 53 & 81 & 134 & 87.3 & 29.3 & 1.12 \\
\hline Female & 200964_at & UBE1 & 423 & 476 & 369 & 304 & 549 & 424.3 & 94.3 & \\
\hline Male & 200964 at & & 282 & 374 & 480 & 339 & 235 & 342.0 & 93.5 & 1.24 \\
\hline Female & 200797_at & PDHA1 & 1814 & 1911 & 1980 & 1579 & 1809 & 1818.6 & 151.7 & \\
\hline Male & 200797_at & & 1228 & 2337 & 1912 & 1474 & 1221 & 1634.4 & 482.8 & 1.11 \\
\hline Female & $200980 \mathrm{~s}$ at & PDHA1 & 186 & 208 & 125 & 167 & 178 & 172.8 & 30.7 & \\
\hline Male & 200980_s_at & & 181 & 144 & 188 & 206 & 158 & 175.4 & 24.6 & 0.99 \\
\hline Female & 207660_at & DMD & 43 & 65 & 42 & 46 & 39 & 47.0 & 10.4 & \\
\hline Male & 207660_at & & 71 & 33 & 50 & 56 & 57 & 53.4 & 13.8 & 0.88 \\
\hline
\end{tabular}

Expression level data for recognised X-linked genes, which did not reach the criteria in the screen expected for $\mathrm{X}$ loci escaping inactivation, but for which previous data support their inactivation status as either escapees or as normally inactivated. PDHA1 and DMD are included for comparison, as representing loci known to be regularly inactivated (eg see text and Carrel et $\mathrm{l}^{5}$ ).

Website references: http://genetics.gene.cwru.edu/willard/data/xin/genesurvey-all.xls

Unfortunately, two well-established escapee loci, MIC2 (cell surface antigen MIC2) and RPS4X (ribosomal protein S4) were not represented on the microarray. PCTAIRE-1, cdc2-related protein kinase (PCTK1) and ubiquitin-activating enzyme (UBE1) were represented and have previously been reported as escaping inactivation ${ }^{5,6}$ although for the latter there have been conflicting reports concerning its inactivation status. ${ }^{4,44}$ Our data indicate that UBE1 is expressed at significant levels in lymphocytes and that there appears to be an excess of female transcripts (see Table 3), which may reflect partial escape from inactivation. PCTK1 also shows a slight excess of female transcripts; however, as for UBE1, the standard deviation intervals overlap and the interpretation concerning their inactivation status remains tentative. In contrast, pyruvate dehydrogensae subunit A1, PDHA1, and the Duchenne muscular dystrophy locus, $D M D$, are known to be regularly inactivated and the ratios we observed for both were consistent with a normal inactivation pattern.

Several loci detected in the screen had female: male ratios of $>2$; however, these all had low absolute detection levels viz ZFX, SYP, SOX3 and CLCN4 (with values c. $<10$ ) and the data for these should be regarded as preliminary, even though the reproducibility of their expression levels in the two sexes was robust. Clearly, the number of loci for which we have provisional information for their escape from inactivation based on the microarray approach is considerably below the $10-20 \%$ figure predicted from some other studies. ${ }^{5,6}$ Among the factors contributing to this discrepancy are that the reliability of any method depends both on absolute expression levels and the extent to which escape from inactivation occurs. Many loci represented on the microarrays are expressed only at low levels in lymphocytes and their inactivation profiles may not be representative of other tissues. In addition, there may be differences in patterns of inactivation between lymphocytes and cell lines and somatic cell hybrids; the latter, in particular, may not reflect the situation in vivo.
Naturally, there are also sex differences in expression for non-X-linked genes. Four probesets gave female to male signal ratios of <0.1: 206700_s_at, 205000_at, 201909_at, and 204409_s_at. These have uncorrected $t$-test $P$-values ranging from 0.0002 to 0.02 and they are all unique $\mathrm{Y}$ chromosome transcripts. At the other extreme, one probe set presents with a ratio of $>10$ and corresponds to the HLA class II DRB4 gene with a common null allele, for which all but two of the female subjects are homozygous. These data indicate the general robustness of the approach. Overall, employing the rudimentary criterion of an uncorrected $t$-test $P$-value of $0.1, \mathrm{X}$ chromosome transcripts show a 3.2-fold excess for female to male high expression, compared with a 2.4 excess for the genome as a whole.

Overall, therefore, we believe that the approach described here will have an important role in the investigation of inactivation patterns in a variety of tissues including the brain and may lead to insights into possible sex differences in behaviour that may result from such dosage differentials.

\section{Acknowledgements}

We acknowledge the support of Professors Peter McGuffin and Robert Plomin in facilitating this investigation, which could not have taken place without the active cooperation of Deborah Keenan, Claire Holdaway and Geoff Scopes, Affymetrix UK Ltd, High Wycombe, Berks.

\section{References}

1 Lyon MF: Some milestones in the history of X-chromosome inactivation. Annu Rev Genet 1992; 26: 16-28.

2 Disteche CM: Escape from $\mathrm{X}$ inactivation in human and mouse. Trends Genet 1995; 11: 17-22.

3 Miller AP, Gustashaw K, Wolff DJ et al: Three genes that escape X chromosome inactivation are clustered within a $6 \mathrm{Mb}$ YAC contig and STS map in Xp11.21-p11.22. Hum Mol Genet 1995; 4: $731-739$. 
4 Carrel L, Clemson CM, Dunn JM et al: X inactivation analysis and DNA methylation studies of the ubiquitin activating enzyme E1 and PCTAIRE-1 genes in human and mouse. Hum Mol Genet 1996; 5: 391-401.

5 Carrel L, Cottle AA, Goglin KC, Willard HF: A first-generation Xinactivation profile of the human X chromosome. Proc Natl Acad Sci USA 1999; 96: 14440-14444, plus updated data: http:// genetics.gene.cwru.edu/willard/data/xin/genesurvey-all.xls.

6 Disteche CM: Escapees on the X chromosome. Proc Natl Acad Sci USA 1999; 96: 14180-14182.

7 Skuse DH, James RS, Bishop DV et al: Evidence from Turner's syndrome of an imprinted X-linked locus affecting cognitive function. Nature 1997; 387: 705-708.

8 Brown CJ, Carrel L, Willard HF: Expression of genes from the human active and inactive X chromosomes. Am J Hum Genet 1997; 60: 1333-1343.

9 Schneider-Gadicke A, Beer-Romero P, Brown LG, Nussbaum R, Page DC: ZFX has a gene structure similar to ZFY, the putative human sex determinant, and escapes X inactivation. Cell 1989; 57: 1247-1258.

10 Fisher EM, Beer-Romero P, Brown LG et al: Homologous ribosomal protein genes on the human $\mathrm{X}$ and $\mathrm{Y}$ chromosomes: escape from $\mathrm{X}$ inactivation and possible implications for Turner syndrome. Cell 1990; 63: 1205-1218.

11 Benjamin D, Van Bakel I, Craig IW: A novel expression based approach for assessing the inactivation status of human X-linked genes. Eur J Hum Genet 2000; 8: 103-108.

12 Sudbrak $\mathrm{R}$ et al: $\mathrm{X}$ chromosome-specific cDNA arrays: identification of genes that escape inactivation and other applications. Hum Mol Genet 2001; 10: 77-83.

13 Page DC, Mosher R, Simpson EM et al: The sex-determining region of the human Y chromosome encodes a finger protein. Cell 1987; 51: 1091-1104.

14 Page DC, Disteche CM, Simpson EM et al: Chromosomal localization of ZFX - a human gene that escapes X inactivation - and its murine homologs. Genomics 1990; 7: 37-46.

15 Palmer MS, Berta P, Sinclair AH, Pym B, Goodfellow PN: Comparison of human ZFY and ZFX transcripts. Proc Natl Acad Sci USA 1990; 87: 1681-1685.

16 Chung J, Lee S-G, Song K: Identification of a human homolog of a putative RNA helicase gene (mDEAD3) expressed in mouse erythroid cells. Kor J Biochem 1995; 27: 193-197.

17 Park SH, Lee SG, Kim Y, Song K: Assignment of a human putative RNA helicase gene, DDX3, to human $\mathrm{X}$ chromosome bands p11.3 $\rightarrow$ p11.23. Cytogenet Cell Genet 1998; 81: 178-179.

18 Greenfield A, Scott D, Pennisi D et al: An H-YDb epitope is encoded by a novel mouse Y chromosome gene. Nat Genet 1996; 14: $474-478$.

19 Greenfield A, Carrel L, Pennisi D et al: The UTX gene escapes X inactivation in mice and humans. Hum Mol Genet 1998; 7: 737-742.

20 Chang PL, Mueller OT, Lafrenie RM et al: The human arylsulfatase-C isoenzymes: two distinct genes that escape from X inactivation. Am J Hum Genet 1990; 46: 729-737.

21 Craig IW, Tolley E: Steroid sulphatase and the conservation of mammalian X chromosomes. Trends Genet 1986; 2: 201-204.

22 Gaspar NJ, Kinzy TG, Scherer BJ, Humbelin M, Hershey JW, Merrick WC: Translation initiation factor eIF-2. Cloning and expression of the human cDNA encoding the gamma-subunit. $J$ Biol Chem 1994; 269: 3415-3422.

23 Ehrmann IE, Ellis PS, Mazeyrat S et al: Characterization of genes encoding translation initiation factor eIF-2gamma in mouse and human: sex chromosome localization, escape from Xinactivation and evolution. Hum Mol Genet 1998; 7: 1725-1737.

24 Tiller GE, Hannig VL, Dozier D et al: A recurrent RNA-splicing mutation in the SEDL gene causes X-linked spondyloepiphyseal dysplasia tarda. Am J Hum Genet 2001; 68: 1398-1407.

$25 \mathrm{Gu} \mathrm{W}$, Malik S, Ito M et al: A novel human SRB/MED-containing cofactor complex, SMCC, involved in transcription regulation. Mol Cell 1999; 3: 97-108.
26 Yoshikawa H, Fujiyama A, Nakai K, Inazawa J, Matsubara K: Detection and isolation of a novel human gene located on $\mathrm{Xp11.2-p11.4} \mathrm{that} \mathrm{escapes} \mathrm{X-inactivation} \mathrm{using} \mathrm{a} \mathrm{two-}$ dimensional DNA mapping method. Genomics 1998; 49: $237-246$.

27 Kaye FJ, Shows TB: Assignment of ubiquilin2 (UBQLN2) to human chromosome Xp11.23-Xp11.1 by GeneBridge radiation hybrids. Cytogenet Cell Genet 2000; 89: 116-117.

28 Zhou J, Mochizuki T, Smeets H et al: Deletion of the paired alpha 5(IV) and alpha 6(IV) collagen genes in inherited smooth muscle tumors. Science 1993; 261: 1167-1169.

29 Oohashi T, Sugimoto M, Mattei MG, Ninomiya Y: Identification of a new collagen IV chain, alpha 6(IV), by cDNA isolation and assignment of the gene to chromosome Xq22, which is the same locus for COL4A5. J Biol Chem 1994; 269: 7520-7526.

30 Montini E, Buchner G, Spalluto C et al: Identification of SCML2, a second human gene homologous to the Drosophila sex comb on midleg $(\mathrm{Scm})$ : a new gene cluster on Xp22. Genomics 1999; 58: $65-72$.

31 Bassi MT, Ramesar RS, Caciotti B et al: X-linked late-onset sensorineural deafness caused by a deletion involving OA1 and a novel gene containing WD-40 repeats. Am J Hum Genet 1999; 64: $1604-1616$.

32 van Slegtenhorst MA, Bassi MT, Borsani G et al: A gene from the Xp22.3 region shares homology with voltage-gated chloride channels. Hum Mol Genet 1994; 3: 547-552.

33 Manser E, Loo TH, Koh CG et al: PAK kinases are directly coupled to the PIX family of nucleotide exchange factors. Mol Cell 1998; 1: $183-192$.

34 Kutsche K, Yntema H, Brandt A et al: Mutations in ARHGEF6, encoding a guanine nucleotide exchange factor for Rho GTPases, in patients with X-linked mental retardation. Nat Genet 2000; 26: $247-250$.

35 Stevanovic M, Lovell-Badge R, Collignon J, Goodfellow PN: SOX3 is an X-linked gene related to SRY. Hum Mol Genet 1993; 2: 2013-2018.

36 Foster JW, Graves JA: An SRY-related sequence on the marsupial X chromosome: implications for the evolution of the mammalian testis-determining gene. Proc Natl Acad Sci USA 1994; 91: 1927-1931.

37 Royer-Pokora B, Kunkel LM, Monaco AP et al: Cloning the gene for an inherited human disorder - chronic granulomatous disease - on the basis of its chromosomal location. Nature 1986; 322: $32-38$.

38 Windhorst DB, Holmes B, Good RA: A newly defined X-linked trait in man with demonstration of the Lyon effect in carrier females. Lancet 1967; 1: 737-739.

39 Gibbons RJ, Suthers GK, Wilkie AO, Buckle VJ, Higgs DR: Xlinked alpha-thalassemia/mental retardation (ATR-X) syndrome: localization to $\mathrm{Xq} 12-\mathrm{q} 21.31$ by $\mathrm{X}$ inactivation and linkage analysis. Am J Hum Genet 1992; 51: 1136-1149.

40 Gibbons RJ, Picketts DJ, Villard L, Higgs DR: Mutations in a putative global transcriptional regulator cause $\mathrm{X}$-linked mental retardation with alpha-thalassemia (ATR-X syndrome). Cell 1995; 80: 837-845.

41 Qian Z, Lin C, Espinosa R, LeBeau M, Rosner MR: Cloning and characterization of MST4, a novel Ste20-like kinase. J Biol Chem 2001; 276: 22439-22445.

42 Kitagawa $\mathrm{K}$, Wang $\mathrm{X}$, Hatada I et al: Isolation and mapping of human homologues of an imprinted mouse gene U2af1-rs1. Genomics 1995; 30: 257-263.

43 Cheung VG, Conlin LK, Weber TM et al: Natural variation in human gene expression assessed in lymphoblastoid cells. Nat Genet 2003; 33: 420-425.

44 Zacksenhaus E, Sheinin R: Molecular cloning, primary structure and expression of the human X linked A1S9 gene cDNA which complements the ts A1S9 mouse L cell defect in DNA replication. EMBO J 1990; 9: 2923-2929. 